\title{
Relationship between spectral variables with RapidEye images and dendrometric variables in teak plantations using principal component analysis
}

\author{
Relação entre variáveis espectrais com imagens RapidEye e variáveis \\ dendrométricas em plantações de teca usando análise de componente \\ principal
}

\author{
${ }^{1}$ Universidade Federal do Paraná - UFPR. Curitiba, PR, Brasil \\ ¿Universidad Nacional de Asunción - UNA. Asunción, Paraguay \\ ${ }^{3}$ Universidade Federal de Mato Grosso - UFMT. Cuiabá, MT, Brasil \\ ${ }^{4}$ Serviço Florestal Brasileiro, Brasília, DF, Brasil \\ ${ }^{5}$ University of Maryland, College Parkdisabled, College Park, United States
}

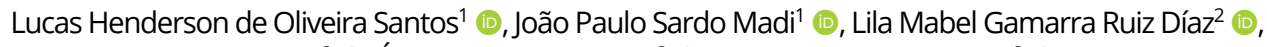
Gláucia Miranda Ramirez ${ }^{3}$ (D) , Édila Cristina de Souza ${ }^{3}$ (1) , Gustavo Manzon Nunes ${ }^{3}$ (1) , Ana Paula Dalla Corte ${ }^{1}$ (1), Mariana Peres de Lima Chaves e Carvalho ${ }^{4}\left(\mathbb{D}\right.$, Carlos Alberto Silva ${ }^{5}$ (i), Samuel de Pádua Chaves e Carvalho ${ }^{3}($ )

\begin{abstract}
How to cite: Santos, L. H. O., Madi, J. P. S., Díaz, L. M. G. R., Ramirez, G. M., Souza, É. C., Nunes, G. M., Corte, A. P. D., Carvalho, M. P. L. C., Silva, C. A., \& Carvalho, S. P. C. (2021). Relationship between spectral variables with RapidEye images and dendrometric variables in teak plantations using principal component analysis. Scientia Forestalis, 49(132), e3655. https://doi.org/10.18671/scifor.v49n132.09
\end{abstract}

\begin{abstract}
Resumo
Informações geotecnológicas são cada vez mais utilizadas para monitorar povoamentos florestais por meio de técnicas e procedimentos analíticos para plantações em larga escala. O objetivo deste estudo foi avaliar a relação entre variáveis espectrais (através de índices de vegetação) usando imagens do satélite RapidEye, variáveis dendrométricas e o índice de uniformidade em plantações de teca, aplicando a análise de componentes principais. 0 experimento foi implantado em 2015, distribuído em 12 unidades experimentais, e foram medidas 50 árvores por unidade. Os dados de campo foram obtidos a partir do inventário florestal realizado em maio de 2019, quando foram coletados dados de altura total (ht) e diâmetro a 1,30 m de altura (dap) de todas as árvores. Foi observada uma forte correlação negativa entre os índices de vegetação e as variáveis dendrométricas com índice de uniformidade. A análise de componentes principais indicou a possibilidade de diferenciar plantações uniformes das não-uniformes. Portanto, é possível prever uniformidade em povoamentos de teca através da correlação entre variáveis dendrométricas e variáveis espectrais do satélite RapidEye.
\end{abstract}

Palavras-chave: Imagens RapidEye; Índice de Vegetação; Índice de Uniformidade; Silvicultura clonal.

\begin{abstract}
Geo-technological information is increasingly used to monitor forest stands through analytical techniques and procedures for large-scale plantations. The objective of this study was to evaluate the relationship between spectral variables (through vegetation index) using images from the RapidEye satellite, dendrometric variables and the uniformity index in teak plantations by applying principal component analysis. The experiment was implemented in 2015, distributed in 12 experimental units, and 50 trees were measured per unit. The field data were obtained from the forest inventory carried out in May 2019, when data on total height (ht) and diameter at $1.30 \mathrm{~m}$ height (dbh) of all trees were collected. A strong negative correlation was observed between vegetation indexes and dendrometric variables with uniformity index. The main component analysis indicated the possibility of differentiating uniform from
\end{abstract}

Financial support: Conselho Nacional de Desenvolvimento Científico e Tecnológico - CNPq.

Conflict of interest: Nothing to declare

Corresponding author: lucashendersonohs@gmail.com

Received: 28 December 2020.

Accepted: 23 July 2021

Editor: Mauro Valdir Schumacher

(c) This is an Open Access article distributed under the terms of the Creative Commons Attribution License, which permits unrestricted use, distribution, and reproduction in any medium, provided the original work is properly cited. 
non-uniform plantations. Therefore, it is possible to predict uniformity in teak stands through the correlation between dendrometric variables and spectral variables from the RapidEye satellite.

Keywords: RapidEye image; Vegetation index; Uniformity index; Clonal silviculture.

\section{INTRODUCTION}

In recent years, the demand for forest products has grown significantly to meet societal needs. According to IBÁ (Indústria Brasileira de Árvores, 2019), the GDP of the Brazilian forest sector increased by $13 \%$ compared to 2017 , due to the increase in exports of forest products. In addition, the sector's export reached historical levels, with products such as cellulose in third place among the products exported by agribusiness.

Teak ranks among the most promising exotic species in Brazil; there are approximately 6.8 million hectares cultivated worldwide, providing high added value products with high economic return (Midgley et al., 2015). Due to its quality and added value, knowing its development processes is fundamental to promote decisions during forest management, resulting in efficient and sustainable exploitation.

In this regard, monitoring the uniformity of the forests is of great relevance, since it makes it possible to evaluate the degree of intraspecific competition, which starts at the closing of the canopy (Binkley, 2004). According to Stape et al. (2010), this competition increases the number of dominated individuals, that is, it decreases the homogeneity of planting. This fact allows classifying regions of the stand with lower productivity. With this knowledge, it is possible to apply silvicultural treatments that favor greater stand uniformity, which can also influence wood growth (Stape et al., 2010; Binkley et al., 2010).

However, high costs can prevent the implementation of new stands, or even make it difficult to monitor existing ones. However, remote sensing technologies (SR) help to increase information from forest inventories, using data detected remotely, efficiently and less costly. Using DataLiDAR (Light Detection and Ranging), Wallace et al. (2016) obtained information on heights and tree identification in support of forest inventory, reducing data acquisition time when compared to traditional methods of measuring with an inventory team in the field.

In addition, there are orbital sensors, where RapidEye ${ }^{\circledR}$ stands out with high spatial and temporal resolution, which can circumvent obstacles such as the presence of clouds. It provides multispectral data with a special $6.5 \mathrm{~m}$ resolution, 5 days temporal and has the Red Edge band. The advantage of this band in the forest area is the greater sensitivity to different vegetation patterns than the NIR band. This is due to the fact that Red Edge is more sensitive to the different levels of chlorophyll that produce large differences in reflectance and transmittance of the leaves (Gitelson et al., 2005; Hatfield et al., 2008).

These characteristics make RapidEye a potential supplier of covariates, which help in digital mapping and in inferring the condition of plant canopies and, therefore, predict variations in characteristics. Some studies have already demonstrated that it is possible to evaluate the behavior of canopies. Ollinger et al. (2008), demonstrated a result of the effects of canopy structure, combined with other factors, such as soil. Through satellite data, canopy reflectance has been used to estimate canopy structure and photosynthetic production (Muraoka et al., 2013). Noda et al. (2021) found distinct eco-physiological processes of plants in spectral profiles of individual leaves and entire crowns in seasonal deciduous forests.

Santos et al., (2021), predicted canopy closure by remote sensing in Tectona grandis L.f.. Wallner et al. (2018), with RapidEye data, confirmed the feasibility of classifying spectrally homogeneous segments of a heterogeneous forest into deciduous and coniferous forest classes. Therefore, it is feasible to use products from this satellite to monitor uniformity in teak plantations, contributing to more assertive inferences in forest management.

Due to the great commercial importance of teak, this study aimed to predict the uniformity in teak forest stands through the correlation between dendrometric variables and spectral variables from the Rapideye satellite, applying the multivariate analysis of principal components. 


\section{MATERIAL AND METHODS}

\section{Area of study}

The study area is located in southeastern Pará State, in the municipality of Santa Maria das Barreiras (Figure 1). The region has an average altitude of $252 \mathrm{~m}$, average annual temperature of $26.9^{\circ} \mathrm{C}$, and total annual rainfall of 2,103 $\mathrm{mm}$. According to the Köppen climate classification, the climate of the region is tropical monsoon (Am) with dry winter (Alvares et al., 2013).

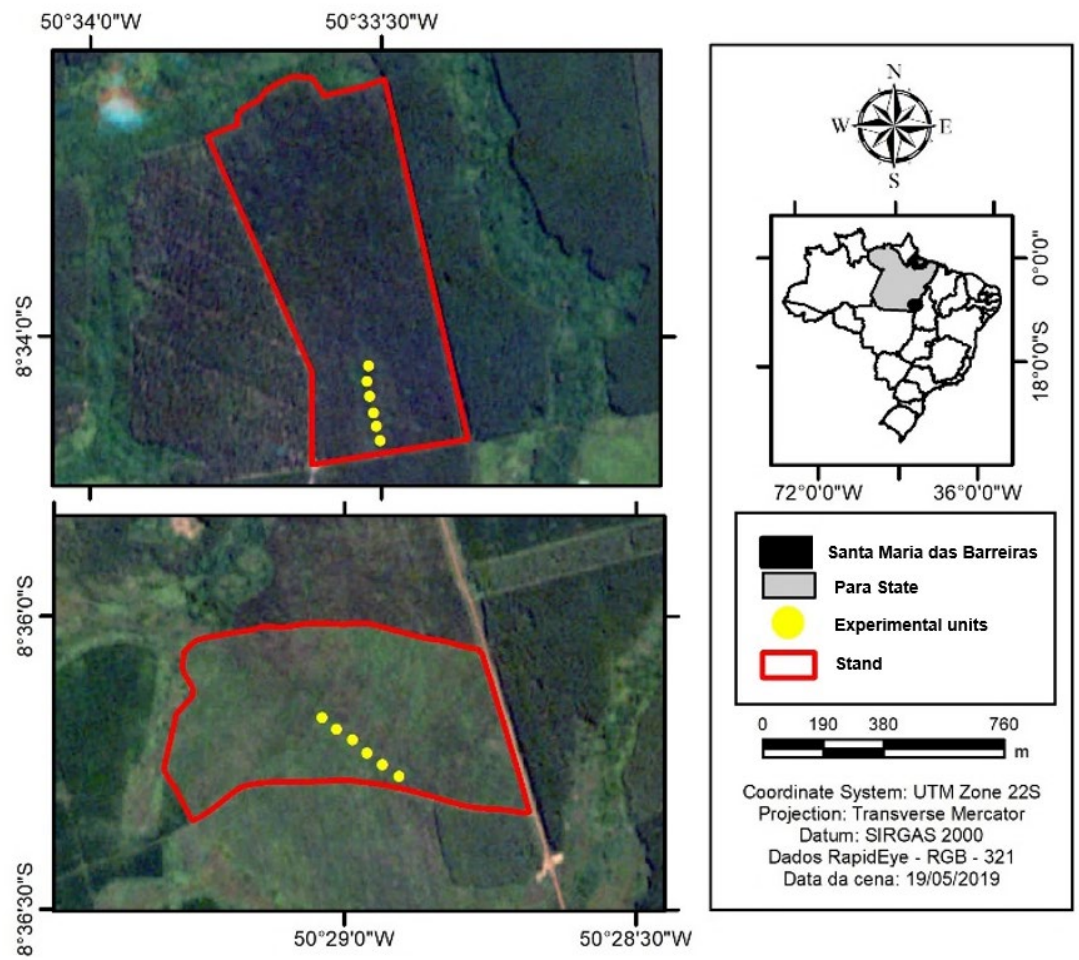

Figure 1: Location of the study area

\section{Obtaining dendrometric variables and calculating the uniformity index}

The experiment commenced in 2015, with the installation of 12 rectangular experimental units (plots), 6 plots of 1,200 $\mathrm{m}^{2}$ with $6 \mathrm{~m} \times 4 \mathrm{~m}$ spacing and 6 of 1,000 $\mathrm{m}^{2}$ plots with $5 \mathrm{~m} \times 4 \mathrm{~m}$ spacing, arranged in bands. In these plots, the diameters were measured at $1.30 \mathrm{~m}$ tree height (dap) and total height (ht) of all individuals. The forest inventory was carried out in 2019, when the census of the plots was done, with 50 trees being measured in each plot, making a total of 600 individuals sampled.

To obtain the uniformity parameters, the methodology developed by Hakamada et al. (2015), in clonal Eucalyptus plantations was adopted. In this study, the PH50 (fifty percentile of heights) was calculated, as described by (Santos et al., 2019). The PH50 index is the accumulated percentage of $50 \%$ of the smallest trees in the plot, sorted in increasing order, according to Equation 1 . In this work, the PH5O is portrayed as IU (uniformity index).

$P H 50=\frac{\sum_{k=1}^{\frac{n}{2}} h t i}{\sum_{k=1}^{n} h t i}$

where: 
$\mathrm{PH} 50=$ cumulative percentage of the height of $50 \%$ of the smallest trees planted; ht $=$ height of the tree $i ; n=$ number of trees planted in order (from smallest to largest).

In the parameterization of the index, the optimal uniformity interval (IOU) was determined, with the objective of evaluating the uniformity behavior according to the production potential. Its upper limit is 0.5 and the lower is the mean of the PH50, subtracted once from the standard deviation (Equation 2).

$$
I O U=\left(\underline{X}_{i j}-1 * S_{i j}\right)<I O U_{i j}<50 \%
$$

where: $I O U=$ Optimal Uniformity Interval of plot $i$ at age $j ; \underline{x}_{i j}=$ mean PH50 of plot $i$ at age $j$; $S_{i j}=$ standard deviation of the mean PH50 of plot $i$ at age $j$.

The IOU makes it possible to characterize the maximum homogeneity and the minimum necessary to be considered uniform. For that, the plots sampled were selected because they had genetically identical plants, ensuring that the uniformity pattern within the plot is only a result of the quality of silvicultural management.

\section{RapidEye image selection and pre-processing}

In order to relate the field data with the SR, a RapidEye image was used, referring to the municipality of Santa Maria das Barreiras/PA, captured in May, 2019. The ortho-rectified scene had less than $20 \%$ cloud cover (in the evaluated plots there was no cloud cover), processing level 3A, with spatial resolution of $6.5 \mathrm{~m}$, and the Mercator Transverse Projection System (UTM), Datum WGS 84.

The digital values in 12 bits were converted to reflectance at the top of the atmosphere, where the digital values of the pixels were first converted to radiance at the sensor level (Equation 3), obtained by multiplying the original digital values by a Radiometric scale factor (BlackBridge, 2013).

$R A D=V D * F E$

where:

$\mathrm{RAD}=$ radiance at the sensor level (unit of measurement $\left.=\mathrm{W} \cdot \mathrm{m}^{-2} \cdot \mathrm{sr} \cdot \mu \mathrm{m}\right) ; \mathrm{VD}=$ original digital value; and $\mathrm{FE}=$ Radiometric scale factor $=0.01$.

In order to transform radiance into reflectance, it is necessary to relate the radiance values to the radiance with which the object is illuminated. Generally, this procedure is performed by means of an atmospheric image correction software. In this way, the atmospheric impact on the radiance values is eliminated at the same time. However, it is possible to neglect the atmospheric influence by calculating the reflectance at the top of the atmosphere (REF), according to (Equation 4) (BlackBridge, 2013).

$R E F=R A D(i) \frac{n^{*} \text { SunDist }^{2}}{\operatorname{EAI}(I)^{*} \cos (\text { SolarZenith })}$

where:

$R E F=$ reflectance value of the top of the atmosphere; $i=$ number of spectral band; $R A D=$ radiance value at the sensor level; SunDist = Earth-Sun distance in astronomical unit (depends on the day, ranges from $0.983289 \mathrm{UA}$ to $1.016710 \mathrm{UA}$, where $\mathrm{UA}=$ astronomical unit); $E A I=$ exo-atmospheric irradiance; and SolarZenith = solar zenith angle in degrees $\left(90^{\circ}\right.$ - angle of solar elevation). In this study, the Earth-Sun distance considered was 1 UA. 
The zenith angle values and the Earth-Sun distance are available in the image header, a file identified as metadata.xml. The exo-atmospheric irradiance (EAI) values, (Table 1), were made available by the technical specifications of BlackBridge (2013). The ArcMap 10.3 program was used to convert radiance to reflectance.

Table 1. Exo-atmospheric irradiance (EAI) values used in this study to convert radiance values at the sensor level to reflectance at the top of the atmosphere

\begin{tabular}{cc} 
Spectral Band & EAI $\left(\mathbf{W} \cdot \mathbf{m}^{-\mathbf{2}} \cdot \boldsymbol{\mu m}\right)$ \\
\hline B1 - 440-510 $\mathrm{nm}$ (Blue) & 1997.8 \\
B2 - 520-590 $\mathrm{nm}$ (Green) & 1863.5 \\
B3 - 630-690 $\mathrm{nm}$ (Red) & 1560.4 \\
B4 - 690-730 nm (Red edge) & 1395.0 \\
B5 - 760-880 nm (Near infrared) & 1124.4 \\
\hline
\end{tabular}

\section{Vegetation indexes}

In addition to the vegetation indexes, the green (Green) and red (Red) bands were individually maintained (Table 2). The choices were made according to the variables that presented the highest correlations, and then included in the principal component analysis.

The vegetation indexes were obtained with the mathematical band tool of the ArcMap 10.3 software. A total of 12 polygons were used, one for each plot sampling $80 \%$ for the pixels. Borders were left, according to visual classification and then the numerical values were extracted. These indexes were chosen due to the presence of the Red Edge band in its composition and indications from the literature.

Table 2. Vegetation indexes analyzed in the present study

\begin{tabular}{|c|c|}
\hline Vegetation indexes & Equation \\
\hline SR - Simple Ratio & $\mathrm{SR}=\mathrm{NIR} / \mathrm{RED}$ \\
\hline $\begin{array}{l}\text { NDVI_Red Edge - Normalized Difference Vegetation } \\
\text { Index with Red Edge band }\end{array}$ & NDVI Red Edge= (NIR-Red Edge)/(NIR+Red Edge) \\
\hline NDVI - Normalized Difference Vegetation Index & $N D V I=(N I R-R E D) /(N I R+R E D)$ \\
\hline DVI - Difference Vegetation Index & $D V I=N I R-R E D$ \\
\hline SAVI - Soil Adjusted Vegetation Index & $\mathrm{SAVI}=(\mathrm{NIR}-\mathrm{RED}) /((\mathrm{NIR}+\mathrm{RED}+\mathrm{L}) *(1+\mathrm{L}))$ \\
\hline EVI - Enhanced Vegetation Index & $E V I=(G *(N I R-R E D)) /(N I R+C 1 * R E D-C 2 * B L U E+L))$ \\
\hline MTCI - MERIS terrestrial chlorophyll index & $\mathrm{MTCl}=(\mathrm{NIR}-$ Red Edge) / (Red Edge-RED) \\
\hline $\mathrm{Cl}$ - Green Chlorophyll Index & $\mathrm{Cl}=(\mathrm{NIR}) / \mathrm{Green}-1$ \\
\hline VARIRed Edge - Visible Atmospherically Resistant Index & VARI = (Red Edge-RED) / (Red Edge-RED) \\
\hline
\end{tabular}

\section{Statistical analysis}

For correlation analysis, the data were interpreted according to the classification proposed by Lopes (2016), described in Table 3.

Table 3. Classification of the values of the linear correlation coefficients

\begin{tabular}{cc}
\hline Correlation Coefficient & Interpretation \\
\hline$r=1 ; r=-1$ & Perfectly positive/negative \\
$0.8 \leq r<1 ;-0.8 \leq r<-1$ & Strongly positive/negative \\
$0.5 \leq r<0.8 ;-0.5 \leq r<-0.8$ & Moderately positive/negative \\
$0.1 \leq r<0.5 ;-0.1 \leq r<-0.5$ & Weak positive/negative \\
$0 \leq r<0.1 ; 0 \leq r<-0.1$ & Tiny positive/negative \\
0 & Nil \\
\hline
\end{tabular}


Pearson's correlation analysis was performed, seeking the degree of relationship between dendrometric variables, vegetation indexes and bands of RapidEye images. The means per plot of each variable obtained with the software R version 3.6.2 (R Core Team, 2020) was used and the spectral values of the vegetation indexes and bands were obtained through the software ArcGis 10.3.

After evaluating the correlation analyses, only the indexes and bands that were correlated with the dendrometric data were separated for the study of multivariate analysis, with moderate (positive / negative) correlation being used as the minimum limit.

In applications involving remote sensing, the variables, whether by means of bands or dendrometrics, show great correlation with each other, so the information that is present in one variable can be explained by another. For this reason, variables that were closer in different stages of uniformity and their behavior were analyzed, explaining the variability of the variables collected with a smaller number of alternative variables.

For principal components analysis, bands B2 and B3 were considered independently, together with the vegetation indexes that had moderate correlation (positive / negative) and indicated dendrometric variables.

Principal Component Analysis (PCA) is the statistical method used to analyze the large combination of pixels, regardless of color scales. The objective was to reduce highly correlated data and project them into a subspace of reduced dimensions using linear combinations of the original data (Ribas \& Vieira, 2011). Such combinations are called principal components and are not correlated with each other.

Data were standardized by the In method and afterwards the number of main components representing most of the total variation above $80 \%$ of influence were selected according to (Silva, 2016). For processing, the correlation matrix was used.

\section{RESULTS AND DISCUSSION}

\section{Uniformity Index}

According to Table 4, only 3 plots were not within the optimal uniformity range.

Table 4. Uniformity values per plot along with the optimal uniformity range

\begin{tabular}{cccc}
\hline Plots & PH50 & Uniformity & IOU \\
\hline 2101 & 0.4669 & Uniform & \\
2102 & 0.4301 & Uniform & \\
2103 & 0.4538 & Uniform & \\
2104 & 0.4547 & Uniform & \\
2105 & 0.3766 & Uniform & \\
2106 & 0.4715 & Uniform & \\
2811 & 0.4206 & Uniform & \\
2812 & 0.3578 & NonUniform & \\
2813 & 0.3546 & NonUniform & \\
2814 & 0.3668 & NonUniform & \\
2815 & 0.3758 & Uniform & \\
2816 & 0.4384 & Uniform & \\
Mean & 0.4139 & & \\
& & &
\end{tabular}

The average PH50 obtained in the study plots was 0.41. Hakamada et al. (2015) used volume data in Eucalyptus and obtained 0.29 as the mean uniformity value at 2 years of age and it increased to 0.42 at 14 years. In clonal teak plantations, Santos et al. (2019) found a 0.45 average uniformity for 9-year data and 0.46 for 11-year data. 
As observed by these authors, young plantations display less uniformity, and this value increases when the plantation is established. The IOU could therefore be established as a single interval for all genetic sites and materials, with a limit lower than 0.37.

Three plots did not fit as being uniform; in the land distribution these were located nearby. According to Binkley et al. (2010), uniform plants in the same sampling unit can be indicators of the adequacy of the supply of resources for growth. Therefore, soil conditions or relief may cause non-uniformity. To evaluate the interference of these non-uniform plots, they were maintained for principal component analysis.

Several studies have reported that the partial or unequal supply of resources, especially in the initial growth phase, can cause an increase in competition between individuals, rendering the plantation heterogeneous (Binkley et al., 2010; Stape et al., 2010).

\section{Correlation of variables}

Figure 2 shows the results of the correlations between the dendrometric data, the calculated indexes and the bands of the RapidEye images, sampled in the 12 plots.

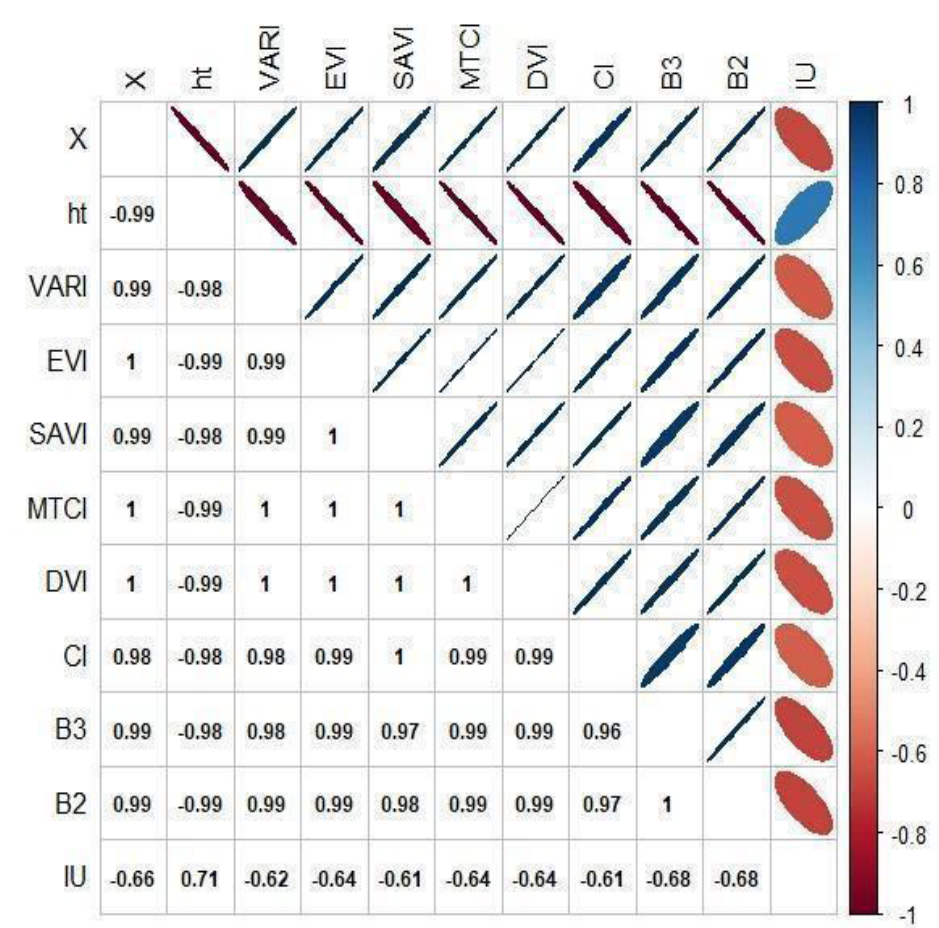

Figure 2. Significant correlation values (for $a=5 \%$ ) between the spectral bands, vegetation index of the RapidEye satellite and dendrometric parameters of teak plantations.

After Pearson's correlation analyses, only the variables that yielded a moderate correlation (positive / negative) when considering the uniformity, were considered, being the bands of green (B2), and red (B3), DVI, SAVI, EVI, MTCI, Cl, VARIRed, ht and IU significant at 95\% probability. The ht had a strong negative correlation with variables of the RapidEye satellite.

According to Santos et al. (2021), the absorption and reflectance of light from the canopy of healthy trees differs from those canopies with physiological disturbances. With the increase in the amount of vegetation and leaf pigments, there is a higher absorption of electromagnetic radiation in the red band (B3), and higher reflectance in the green band (B2).

As for the canopy, the radiation that reaches it is absorbed, transmitted or reflected by leaves, branches and soil surface. The reflectance configured by this combination of factors is used to estimate the structure of the canopy (Muraoka et al., 2013). In deciduous forests such as teak, phenology phenomena are apparently more represented by seasonal changes related 
to leaf growth and fall, as well as spectral properties that change according to the stage and position of the vegetation canopies (Noda et al., 2021).

Motohka et al., (2010), showed that the green band and red band reflectance patterns of deciduous forests are unique during the early leaf growing season. Green band reflectance increased after leaf emergence and decreased after canopy closure, while red band reflectance continued to decrease after leaf emergence. Therefore, orbital images can be used to assist in the detection of different spectral canopy patterns (Oumar \& Mutanga 2013).

In the case of vegetation indexes, a factor that may have contributed to the negative correlation with total height of the teak canopy is the increase in the amount of shadow that occurs due to the different heights of the crowns. This pattern was also observed by Ramirez et al. (2006), when evaluating vegetation index in coffee plantations.

In the principal component analysis for the plots, the variables in Dimensions 1 (CP1) and 2 (CP2) explain $99.3 \%$ of the total variation of the data (Figure 3). The value for CP1 is 0.936 , the first dimension explains $93.6 \%$ of the total variance. Similarly, the value for CP2 is 0.057 , that is: the second dimension explains $5.7 \%$ of the total variance.

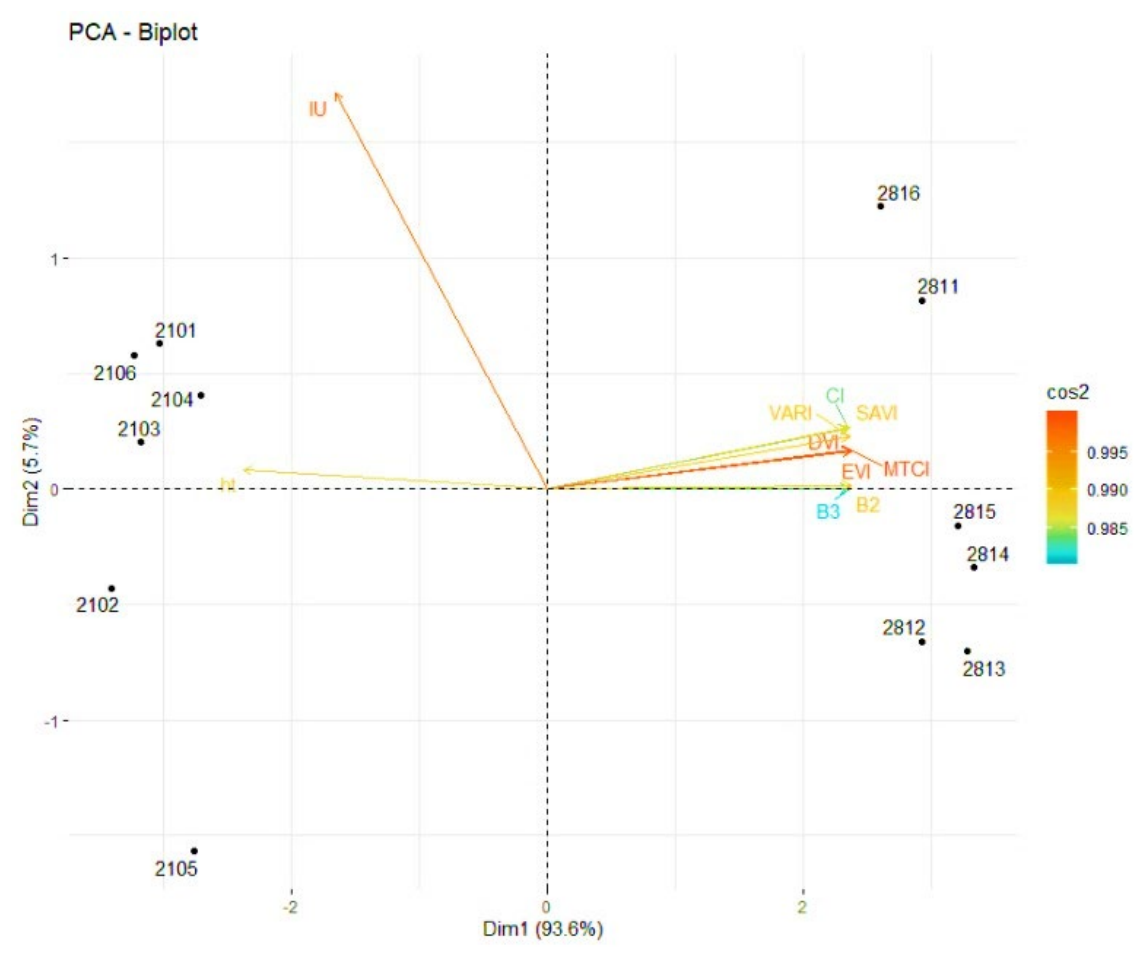

Figure 3. Principal Components Analysis Graph.

The longer the length of a vector, the greater influence it will have on the analysis (Borcard et al., 2011). Plots 2812, 2813 and 2814 were not characterized as uniform for the year of the inventory. It was possible to observe that the IU was on the opposite side of the non-uniform plots, indicating its inverse correlation.

The dimensions were summarized from 11 original variables to 2 principal components. Both analyses showed losses of less than $20 \%$ of the information in the first two dimensions. It was possible to observe that the vegetation indexes are all in the first quadrant $(2,1)$, having no influence in relation to non-uniform plots. The total height indicates a high negative correlation with the PCA variables, but in a lower hierarchy than the IU, that is, uniformity index produced a better result for behavior analysis of the variables than the total height. 
Therefore, for the plantation in question, in the dimensions CP1 and CP2, the variables $\mathrm{MTCl}, \mathrm{DVI}, \mathrm{EVI}, \mathrm{IU}, \mathrm{SAVI}, \mathrm{Cl}$ and VARI are the most influential for PCA in relation to uniform plots and have no influence in relation to non-uniform plots.

Just as the uniformity index is composed in function of the height variable, the bands constitute the vegetation indexes. The vegetation index was developed to better explain the spectral properties of the vegetation and is related to the biophysical parameters of the vegetation cover, being able to characterize parameters such as silvicultural conditions, species and uniformity (Ponzoni \& Shimabukuro, 2010).

Working with vegetation index helps the observation and extraction of vegetation behavior patterns (Xiao et al., 2004). As an example, according to Cui \& Kerekes (2018), vegetation index that make use of the red edge band remarkably improve the accuracy in the analysis of biophysical parameters of vegetation, as this wavelength is sensitive to the biochemical parameters, being mainly influenced by the concentration of chlorophyll.

According to Gabrielsen (1948) and Kozai \& Nozue (2018), it is possible to observe drops in reflectance and absorption of green light as related to the thickness and concentration of chlorophyll in the leaf.

Thus, the differences in the height of crowns generate shadows that interfere with the sensors' capture sensitivity, causing a discrepancy in the capture of the vegetation indexes. Therefore, canopies with non-uniform strata will have a different spectral response, which is observed in the vegetation indexes. This observation can be used to explain the importance of vegetation index in the formation of CP1.

As for the indexes, DVI is sensitive to the distinction between soil and vegetation; however, it does not explain the difference between reflectance and brightness caused by atmospheric effects or shadows (Tucker, 1979). This is similar to the VARI, which has its greatest use in estimating the fraction of vegetation in a scene with low sensitivity to atmospheric effects. This confirms what was described by Gitelson et al. (2005), where the Red Edge band allows the index to be more sensitive to the different chlorophyll levels present in the leaves. Such a fact helps to differentiate the types of biomass.

SAVI has soil correction adjustment; in this study the Teak plantation was 4 years old. Due to its canopy architecture and its age, the canopies had not yet touched, therefore, many spaces between the canopies were present in the image with the presence of many grasses.

The EVI has the characteristic of reducing the influence of the signal from the soil and the atmosphere, detecting regions with higher density of biomass (Ferreira et al., 2008). Its great advantage over non-uniform canopies is the introduction of the blue band and the constants obtained empirically, making the index sensitive to discrimination of structural variations in the vegetation of densely vegetated areas (Huete et al., 2002).

Therefore, like Schliemann \& Bockheim (2011), the study confirmed that the characterization of canopy damage can be performed using orbital digital images. The variation in the spectral response creates a contrast between the object and others around it, giving rise to the possibility of determining the size and shape of the object. This confirms that the canopy structure changes the behavior influence of variables in principal component analysis (Pettorelli et al., 2014).

\section{CONCLUSIONS}

For teak, the vegetation indexes MTCI, DVI, EVI, IU, SAVI, Cl and VARI have an influence on the PCA in relation to uniform plots, but have no influence on non-uniform plots.

The principal component analysis indicated the possibility of differentiating uniform and nonuniform plantations. Therefore, it is possible to predict uniformity in teak stands through the correlation between dendrometric variables and spectral variables from the RapidEye satellite.

Studies using active sensors are indicated and can help to obtain more accurate answers regarding uniformity. Furthermore, plantations with multiple ages might have different responses. 


\section{REFERENCES}

Alvares, C. A., Stape, J. L., Sentelhas, P. C., \& de Moraes Gonçalves, J. L. (2013). Modeling monthly mean air temperature for Brazil. -. Theoretical and Applied Climatology, 113(3-4), 407-427. http://dx.doi.org/10.1007/s00704-012-0796-6.

Binkley, D. (2004). A hypothesis about the interaction of tree dominance and stand production through stand development. Forest Ecology and Management, 190(2-3), 265-271. http://dx.doi.org/10.1016/j.foreco.2003.10.018.

Binkley, D., Stape, J. L., Bauerle, W. L., \& Ryan, M. G. (2010). Explaining growth of individual trees: light interception and efficiency of light use by Eucalyptus at four sites in Brazil. Forest Ecology and Management, 259(9), 1704-1713. http://dx.doi.org/10.1016/j.foreco.2009.05.037.

BlackBridge. (2013). Satellite Imagery Product Specifications. Delivering the world version 6.0. Retrieved in 2020, December 28, from https://www.planet.com/products/satellite-imagery/files/160625RapidEye\%20Image-Product-Specifications.pdf

Borcard, D., Gillet, F., \& Legendre, P. (2011). Numerical Ecology with R. (306 p.). New York: Springer. http://dx.doi.org/10.1007/978-1-4419-7976-6.

Cui, Z., \& Kerekes, J. P. (2018). Potential of red edge spectral bands in future landsat satellites on agroecosystem canopy green leaf area index retrieval. Remote Sensing, 10(9), 1458. http://dx.doi.org/10.3390/rs10091458.

Ferreira, L. G., Ferreira, N. C., \& Ferreira, M. E. (2008). Sensoriamento remoto da vegetação: evolução e estado-da-arte. Acta Scientiarum. Biological Sciences, 30(4), 379-390. http://dx.doi.org/10.4025/actascibiolsci.v30i4.5868.

Gabrielsen, E. K. (1948). Effects of different chlorophyll concentrations on photosynthesis in foliage leaves. Physiol Plant. 1(1):5-37. http://dx.doi.org/10.1111/j.1399-3054.1948.tb07108.x.

Gitelson, A. A., Viña, A., Ciganda, V., Rundquist, D. C., \& Arkebauer, T. J. (2005). Remote estimation of canopy chlorophyll content in crops. Geophysical Research Letters, 32(8), L08403. http://dx.doi.org/10.1029/2005GL022688.

Hakamada, R. E., Stape, J. S., Lemos, C. C. Z., Emanuel, A., Almeida, A., \& Silva, L. F. (2015). Uso do inventário florestal e da uniformidade entre árvores como ferramenta de monitoramento da qualidade silvicultural em plantios clonais de eucalipto. Scientia Forestalis, 43(105), 27-39. Retrieved in 2020, December 28, from https://www.ipef.br/publicacoes/scientia/nr105/cap03.pdf

Hatfield, J. L., Gitelson, A. A., Schepers, J. S., \& Walthall, C. L. (2008). Application of spectral remote sensing for agronomic decisions. Agronomy Journal, 100(Suppl 3), S117-S131. http://dx.doi.org/10.2134/agronj2006.0370c.

Huete, A., Didan, K., Miura, T., Rodriguez, E. P., Gao, X., \& Ferreira, L. G. (2002). Overview of the radiometric and biophysical performance of the MODIS vegetation indices. Remote Sensing of Environment, 83(1-2), 195-213. http://dx.doi.org/10.1016/S0034-4257(02)00096-2.

Indústria Brasileira de Árvores - IBÁ. (2019). Relatório IBA 2019. São Paulo: IBÁ. Retrieved in 2020, December 28, from https://iba.org/datafiles/publicacoes/relatorios/iba-relatorioanual2019.pdf

Kozai, T., \& Nozue, M. (2018). Reconsidering the fundamental characteristics of photosynthesis and LEDs. In T. Kozai (Eds.), Smart plant factory (pp. 169-181). Singapore: Springer. https://doi.org/10.1007/978-981-13-1065-2_11.

Lopes, L. F. D. (2016). Métodos quantitativos. Santa Maria: Universidade Federal de Santa Maria.

Midgley, S., Somaiya, R. T., Stevens, P. R., Brown, A., Kien, N. D., \& Laity, R. (2015). Planted teak: global production and markets, with reference to Solomon Islands. ACIAR Technical Reports 85 . Canberra: Australian Centre for International Agricultural (2015). Retrieved in 2020, December 28, from http://www.teaknet.org/download/Jinesh_php/Midgley\%20et\%20al.pdf

Motohka, T., Nasahara, K. N., Oguma, H., \& Tsuchida, S. (2010). Applicability of Green-Red Vegetation Index for Remote Sensing of Vegetation Phenology. Remote Sensing, 2(10), 2369-2387. http://dx.doi.org/10.3390/rs2102369.

Muraoka, H., Noda, H. M., Nagai, S., Motohka, T., Saitoh, T. M., Nasahara, K., \& Saigusa, N. (2013). Spectral vegetation indices as the indicator of canopy photosynthetic productivity in a deciduous broadleaf forest. Journal of Plant Ecology, 6(5), 393-407. http://dx.doi.org/10.1093/jpe/rts037.

Noda, H. M., Muraoka, H., \& Nasahara, K. N. (2021). Plant ecophysiological processes in spectral profiles: perspective from a deciduous broadleaf forest. Journal of plant research, 134(4), 737-751. PMid:33970379. http://dx.doi.org/10.1007/s10265-021-01302-7. 
Ollinger, S. V., Richardson, A. D., Martin, M. E., Hollinger, D. Y., Frolking, S. E., Reich, P. B., \& Schmid, H. P. (2008). Canopy nitrogen, carbon assimilation, and albedo in temperate and boreal forests: functional relations and potential climate feedbacks. Proceedings of the National Academy of Sciences of the United States of America, 105(49), 19336-19341. http://dx.doi.org/10.1073/pnas.0810021105.

Oumar, Z., \& Mutanga, O. (2013). Using WorldView-2 bands and indices to predict bronze bug (Thaumastocoris peregrinus) damage in plantation forests. International Journal of Remote Sensing, 34(6), 2236-2249. http://dx.doi.org/10.1080/01431161.2012.743694.

Pettorelli, N., Laurance, W. F., O'brien, T. G., Wegmann, M., Nagendra, H., \& Turner, W. (2014). Satellite remote sensing for applied ecologists: opportunities and challenges. Journal of Applied Ecology, 51(4), 839-848. http://dx.doi.org/10.1111/1365-2664.12261.

Ponzoni, F. J., \& Shimabukuro, Y. E. (2010). Sensoriamento remoto no estudo da vegetação. (128 p.). São José dos Campos: Parêntese.

R Core Team. (2020). R: a language and environment for statistical computing. Vienna, Austria: R Foundation for Statistical Computing. Retrieved in 2020, December 28, from https://www.Rproject.org/

Ramirez, G. M., Zullo Junior, J., Assad, E. D., \& Pinto, H. S. (2006). Comparação de dados dos satélites Ikonos-II e Landsat/ETM+ no estudo de áreas cafeeiras. Pesquisa Agropecuária Brasileira, 41(4), 661666. Retrieved in 2020, December 28, from https://www.scielo.br/pdf/pab/v41n4/29814.pdf

Ribas, J. R., \& Vieira, P. R. C. (2011). Análise multivariada com o uso do SPSS. Rio de Janeiro: Editora Ciência Moderna. p. 272.

Santos, I. C. L., dos Santos, A., Costa, J. G., Rosa, A. M., Zanuncio, A. J. V., Zanetti, R., Oumar, Z., \& Zanuncio, J. C. (2021). Tectona grandis canopy cover predicted by remote sensing. Precision Agriculture, 22(3), 647-659. http://dx.doi.org/10.1007/s11119-020-09748-w.

Santos, L. H. O., Ramirez, G. M., Roque, M. W., Chaves e Carvalho, M. P. L., Ruiz Díaz, L. M. G., \& Chaves e Carvalho, S. P. (2019). Correlação entre uniformidade e NDVI em povoamentos de Tectona grandis L. f. BIOFIX Scientific Journal., V4(2), 130-136. http://dx.doi.org/10.5380/biofix.v4i2.65085.

Schliemann, S. A., \& Bockheim, J. G. (2011). Methods for studying tree fall gaps: a review. Forest Ecology and Management, 261(7), 1143-1151. http://dx.doi.org/10.1016/j.foreco.2011.01.011.

Silva, A. R. (2016). Métodos de análise multivariada em R (167 p.). Piracicaba: FEALQ.

Stape, J. L., Binkley, D., Ryan, M. G., Fonseca, S., Loos, R. A., Takahashi, E. N., Silva, C. R., Silva, S. R., Hakamada, R. E., Ferreira, J. M. A., Lima, A. M. N., Gava, J. L., Leite, F. P., Andrade, H. B., Alves, J. M., Silva, G. G. C., \& Azevedo, M. R. (2010). The Brazil Eucalyptus potential productivity project: influence of water, nutrients and stand uniformity on wood production. Forest Ecology and Management, 259(9), 1686-1694. http://dx.doi.org/10.1016/j.foreco.2010.01.012.

Tucker, C. (1979). Red and photographic infrared linear combinations for monitoring vegetation. Remote Sensing of Environment, 8(2), 127-150. http://dx.doi.org/10.1016/0034-4257(79)90013-0.

Wallace, L., Lucieer, A., Malenovský, Z., Turner, D., \& Vopěnka, P.. (2016). Assessment of forest structure using two UAV techniques: a comparison of airborne laser Scanning and Structure from Motion (SfM) Point Clouds. Forests, 2016(7), 62. http://dx.doi.org/10.3390/f7030062.

Wallner, A., Elatawneh, A., Schneider, T., Kindu, M., Ossig, B., \& Knoke, T. (2018). Remotely sensed data controlled forest inventory concept. European Journal of Remote Sensing, 51(1), 75-87. http://dx.doi.org/10.1080/22797254.2017.1403295.

Xiao, X. M., Zhang, Q., Braswell, B., Urbanski, S., Boles, S., Wofsy, S., Moore III, B., \& Ojima, D. (2004). Modeling gross primary production of temperate deciduous broadleaf forest using satellite images and climate data. Remote Sensing of Environment, 91(2), 256-270.

Authors' contributions: LHOS: conceptualization, Data curation, Investigation, Methodology, Project administration, software, supervision, validation, visualization, writing - original draft; JPSM and LMGRD: conceptualization, data curation, formal analysis, software, supervision, writing - review \&amp; editing, writing; GMR and ECS: data curation, methodology, resources, software, supervision, validation, visualization; GMN and APDC: data curation, formal analysis, resources, supervision, validation, visualization; MPLCC and CAS: formal analysis, supervision, validation, visualization; SPCC: data curation, formal analysis, resources, supervision, validation, visualization, project administration. 